\title{
Choosing independence or affiliation: The case of Portuguese four- and five-star hotels
}

Tourism and Hospitality Research 2020, Vol. 20(4) 450-465 (C) The Author(s) 2020 Article reuse guidelines: sagepub.com/journals-permissions DOI: 10.1177/1467358420914369 journals.sagepub.com/home/thr SAGE

\author{
Sofia Almeida (1) and Valerie Sheppard \\ Faculty of Tourism \& Hospitality, Universidade Europeia, Lisboa, Portugal
}

\section{Carlos Costa}

School of Economics, Management, Industrial Engineering and Tourism (DEGEIT), Universidade de Aveiro, Aveiro, Portugal

\section{José Manuel Simões}

Institute of Geography and Spatial Planning (IGOT), Universidade de Lisboa, Lisboa, Portugal

\section{Raquel Costa}

Faculty of Health Sciences, Universidade Europeia, Lisboa, Portugal

\begin{abstract}
In the increasingly competitive hotel environment, decision-makers must consider the risks and benefits of remaining independent or affiliating with a brand or consortium. This research sought to understand the level of importance associated with a set of motivating factors considered by Portuguese four- and five-hoteliers as it relates to remaining independent or affiliating. The study results suggest that independent hoteliers rank control over decision making and shorter decision making as most important in remaining independent, and increased sales and more aggressive marketing as most important in the decision to affiliate. Affiliated hoteliers rank shorter decision making and absence of fees as most important in remaining independent, and increased sales, brand value, and more aggressive marketing as most important in the decision to affiliate. Interestingly, independence and freedom were considered less important in the decision to remain independent, by all respondents. We apply Hofstede's cultural dimensions theory to explain some of the key findings.
\end{abstract}

\section{Keywords}

Motivational factors, hotel independence versus affiliation, Hofstede's cultural dimensions theory, Portugal

\section{Introduction}

Worldwide tourism arrivals reached 1.4 billion international tourist arrivals in 2018, two years ahead of forecasts (United Nations World Tourism Organization (UNWTO), 2019). This represents an increase of $6 \%$ over the previous year (2017) and represents the second strongest year since 2010 (UNWTO, 2019). These increases are reflected in the international hotel sector which has experienced similar recovery following the global economic recession which began in 2008 (Papatheodorou et al., 2010).

Portugal's hotel sector has been a part of this recovery. According to Instituto Nacional de Estatística

\section{Corresponding author:}

Sofia Almeida, Faculty of Tourism \& Hospitality, Universidade Europeia, Campus Lispolis, Rua Laura Ayres, n 4 , Lote 171600 510 Telheiras, Lisboa, Portugal.

Email: salmeidaduniversidadeeuropeia.pt 
(INE) (2017), Portugal experienced a $23.0 \%$ increase in tourism arrivals in 2017 when compared to 2016 . In 2010, the Portuguese hotel sector provided accommodation to 13.5 million guests corresponding to 37.4 million overnight stays (INE, 2010). By 2017 (INE), the number of guests had grown to 24.1 million and overnight stays reached 65.8 million.

In Portugal, the growth of the hotel sector has included an increase in the number of independent hotels as well as branded hotel chains. Small and independent hotels often look for status and recognition from a strong identity brand umbrella. According to O'Neill and Mattila (2004), branding is increasingly important in a global environment. The American Marketing Association's (AMA) (1960) definition of a brand is one of the most cited. Specifically, they define a brand as a name, design, term, symbol, or any other feature that identifies one seller's goods or services as being distinct from those of another seller. Chain branded hotels are considered to have more power (through their brand and reputation) and more resources to help their members to achieve their goals.

The decision to remain independent or to affiliate with a brand is an important issue for independent hotels (see Almeida, 2018; Braun, 2013; Carlbäck, 2012, 2016; Holverson et al., 2010; Holverson and Revaz, 2006; Ivanov and Ivanova, 2016; Koutoulas, 2016; Morrison, 1998; Mulindwa and Ulu, 2016; O'Neill and Carlbäck, 2011; O'Neill and Mattila, 2004; Rushmore, 2005), as it influences marketing strategies and many other operational and financial factors. Carlbäck's (2012) study, for example, suggests that hotels affiliated with a hotel brand have higher occupancy rates and a higher financial return than independent hotels. His study demonstrated that revenue per available room (RevPar) for small independent hotels ( 25 rooms) is less than half of the RevPar for hotels belonging to a chain, of similar size. Therefore, affiliation is a compelling option for small, independent hotels, as they can benefit from the attributes provided by a network of hotels, while maintaining their uniqueness.

Although previous researchers have documented the advantages and disadvantages associated with independence and affiliation, much is yet to be understood about the importance of the various motivational factors involved in the decision-making process, as it relates to remaining independent or affiliating. Therefore, the first objective of this study was to understand the degree of importance associated with the various motivational factors which lead Portuguese four- and five-star hotel decision makers to choose to remain independent or affiliate. The second objective was to verify if there are significant differences in the perceptions of independent and affiliate hotels concerning the importance of the various motivational factors. To explain some of the study's unique findings we returned to the literature to better understand the impact of culture on business decision making. Specifically, we turn to Hofstede's cultural dimension theory to provide a possible explanation of the cultural aspects associated with the results of this study. Overall, this study advances existing knowledge, particularly as it relates to better understanding how cultural nuances may affect the business environment and, specifically, Portuguese hoteliers' motivations for remaining independent or affiliating.

We begin by reviewing key pieces of literature considered of most relevance to this study, namely: the characteristics of independent and affiliated hotels; the benefits and risks associated with independence and affiliation; and, the decision-making factors associated with choosing affiliation or dependence. To explain some of the findings we also examine literature related to Hofstede's cultural dimensions theory. The literature review is followed by a description of the methods used to undertake the study, which leads to the results, discussion of the findings, and limitations. We conclude by discussing the implications of the study and areas for future research.

\section{Literature review}

\section{Characteristics of an independent hotel}

Bardi (2003) defines an independent hotel as one that is not associated with a franchise, marketing, or management agreement. The owner is often involved in the management of the hotel, under the guidance of its own board (Almeida, 2018). Indeed, many independent hotels often have a history and/or are family run which enables them creative freedom to provide unique experiences to their guests (Xotels, 2019). These intangible factors can enhance the success of an independent hotel, along with a strong and effective marketing department, a convenient location, and the hotel's overall design and planning choices (Lawson, 1997).

Other features of independent hotels include room rates that are similar to affiliated hotels, along with rooms decorated in different styles, and inviting dining rooms. Their location can be in the center of the city, the suburbs, alongside road and highways, and or near an airport (Bardi, 2003). Rushmore (2005) describes the profile for an independent hotel as consisting of a good location, a prominent name, an exceptional management team, and the usual amenities. They may be housed in buildings of architectural significance, and can include boutique hotels, convention-style properties, and or extended-stay properties. However, it is important to note that many 
of these features are not unique to independent hotels. Indeed, independent hotels can join an affiliation or consortium in their current geographical location, and often maintain many of their original design and layout features.

\section{Benefits and risks associated with independence}

A review of the literature reveals that there are many benefits to remaining independent. Generally, the benefits to remaining independent are identified as follows: maintaining individuality; proximity to the consumer and market needs; customer relationship management (CRM) advantages; exemplary service and guest recognition; the ability to respond to guest needs related to security and privacy; better service and attention to detail; greater value for money; possibility of co-branding with partners; and the ability to continuously make independent decisions related to innovation in design and concept (see Almeida, 2018; Carlbäck, 2012; Holverson and Revaz, 2006; Marvel, 2004; PricewaterhouseCoopers, 2006; Quesada and Ruiz, 2006; Quintas, 2006).

On the other hand, the risks associated with independence have been well described in the literature. For example, Holverson and Revaz's (2006) research compared affiliated hotels with small, independent hotels and found that the latter have difficulties in the following areas: marketing, standards of quality, cost control, and financial resources. Their research also indicated that independent hotels may suffer from an underutilization of management resources, lower profit margins, employment issues, weaker bargaining power, lack of representation on electronic channels, and a greater fluctuation in demand throughout the year. Similarly, independent hotels may be at much greater risk during economic slowdowns, particularly if they have a limited marketing budget. According to Singh and Dev (2014), there is a positive relationship between marketing expenditure and firm performance, particularly during economically challenging times.

The literature also reveals that independent hotels have, historically, been challenged in the areas of employment and technology. For example, Freund de Klumbis (2002) explains that small, independent hotels often have fewer resources to hire dedicated staff. They are also challenged in the ability to invest in technology solutions. For this reason, they are can be disadvantaged when accessing critical information, such as new trends. However, this situation has, over time, become less of a disadvantage, as technology has advanced and become more accessible in the almost twenty years since Freund de Klumbis' research took place.
More recently, the literature reveals another threat to the hotel industry and that is in relation to the sharing economy, particularly Airbnb (Akbar and Tracogna, 2018). For example, Guttentag and Smith's (2017) research suggests that users consider Airbnb to be superior to budget hotels and motels. Further, their research illustrated that users commonly substituted Airbnb in place of mid-range hotels, but were less likely do so as it related to upscale hotels. These findings have implications for both independent and affiliated hotels, particularly as it relates to maintaining and/or growing market share.

\section{Decision-making factors related to remaining independent}

Overall, there is a lack of literature that discusses the factors that are considered important in the decisionmaking process of hoteliers who decide to remain independent. There are a few noteworthy exceptions, such as Carlbäck's (2008) research undertaken with Swedish hotel decision makers. Specifically, in his interviews with 12 independent hotel managers and 5 affiliated managers in Sweden, he identified a variety of important factors for hotels to consider when deciding to remain independent or affiliate with a hotel brand. The decision-making factors considered important related to remaining independent as identified in his study are: freedom; independence; control over decisions; shorter decision making timelines; shorter decision making processes; cost reduction for the company; better exploitation of internal resources; marketing features based on the unique characteristics of the business; and absence of fees and royalties.

Another factor considered important in the decision to remain independent is the history of the hotel. This is particularly so in Europe. As Holverson and Revaz (2006) observe, the European market is characterized by a higher percentage of small, independent, and often family-owned and operated hotels. It is not unusual for these hotels to be hundreds of years old, and as such they have developed a loyal clientele over time. Overall, these hotels have satisfactory occupancy rates, revenues, and profits and it is, therefore, unlikely they would benefit from affiliating. Consequently, the hotel's history, the family's history with the hotel, along with cultural aspects related to ownership are important and unique characteristics that influence the decision of many European hoteliers to remain independent.

\section{Characteristics of an affiliated hotel}

Affiliated hotels are those which are associated with hotel chains and/or a hotel marketing consortium 
(i.e. the hotel is part of a bigger network). As noted in the previous section, characteristics of an affiliated hotel are not all that different from those of an independent hotel, with the exception that managers and owners involved in an affiliation usually have less independence in decision making. Affiliation is an enticing option for independent hotels, particularly as it relates to the number of locations, category and size of the various affiliated properties within the consortium (Ivanova and Ivanov, 2015). In other words, an affiliated hotel can benefit from the attributes of the other hotels within the affiliation or consortium.

To become a part of a consortium or an affiliation, an independent hotel voluntarily decides to pay an annual fee which enables the hotel to buy into an exchange of services and benefits (Pizam and Holcomb, 2008). The affiliation process begins with the decision to affiliate, after which the decision makers must then select the type of affiliation (franchise or an association within a consortium) and finally decide as to the specific brand to represent the hotel (Almeida, 2018; Ivanova and Ivanov, 2015). Franchising, which is a different option for hotel owners and not the focus of this research, is a form of organization based upon a legal agreement between the parent company (franchisor) and a local business owner (franchisee). One of the main differences between franchising and a consortium is the payment of royalties. As it relates to a franchise agreement, the franchisee is required to pay for the rights to use the brand and is allowed to use the franchisor's success formula. In contrast, a consortium has an umbrella brand which the members are permitted to use (if they choose), as part of the fees paid, in all their promotional materials and as it relates to the delivery of goods and services.

\section{Benefits and risks associated with affiliation}

Many researchers have described the variety of benefits related to affiliation. These benefits include: (1) brand associated benefits; (2) economies of scale related to the multinational nature of chain hotels; (3) more professional management; (4) rationale of operation; (5) lower operating costs; (6) better service provision; (7) continuous improvement of human resources; (8) diversified career opportunities for employees; (9) better profitability and greater probabilities of economic success (see Andersen, 2000; Contractor and Kundu, 1998; Holverson and Revaz, 2006; Ivanova and Rahimi, 2016; Jiang and Peng, 2011; Miguel, 2001; O’Neill and Carlbäck, 2011).

According to O'Neill and Carlbäck (2011), affiliations are a lever for the growth and development of hotels. The chain, and the hotels within the chain, both benefit with the addition of new hotels in a variety of ways, including: (1) increasing financial resources (through the payment of franchise/management/ lease fees); (2) greater knowledge of local markets (demand, competition, suppliers and the legal system) (Jiang and Peng, 2011); (3) higher market share; (4) freedom to define net prices; (5) greater returns for investors; (6) enhanced growth potential; (7) improved customer loyalty (Andersen, 2000); (8) lower operating costs; (9) better service provision; (10) continuous improvement of human resources; (11) career possibility; (12) better profitability; and (13) greater probabilities of economic success (Miguel, 2001). According to Andersen (2000) while high cost items (e.g. reservation systems, loyalty programs) are expensive to set up and maintain, these costs can be distributed over a greater number of hotel units, creating an advantage over independent hotels.

Even soft brand affiliated hotels benefit from the brand (Hoisingtone, 2019). A soft band hotel is defined by Raugh, the CEO of RAR Hospitality, as a hotel that is backed by a brand, but that the brand name does not appear on the building (see Hoisingtone, 2019). Raugh continues on to state that being affiliated is a benefit in recessionary times, as the brand acts like an insurance policy. As he states, brands (or affiliated hotels) have the resources that enable business to continue through such economically challenging times (see Hoisingtone, 2019).

According to Holverson and Revaz (2006: 407) there are risks for hotel decision makers who consider affiliation to a brand, particularly as it relates to fees and royalties. Indeed, the risks associated with affiliation may outweigh the benefits received for some hotels. O'Neill and Carlbäck (2011) agree, noting that affiliation is not a risk-free process, as it involves membership costs and the loss of administrative autonomy. Interestingly, Holverson and Revaz's (2006) research findings suggested that the loss of decision-making control was not an important decision-making factor for hotel decision makers. Later research by Holverson et al. (2010: 40) appears to collaborate this finding, indicating that hotel decision makers perceived the largest risk associated with affiliation to be limited positioning and targeting $(42 \%)$, high fees/commissions (15\%), followed by a lack of hotel independence $(12 \%)$.

\section{Decision-making factors related to affiliation}

While the process of affiliation is an increasingly complex decision to make and process to undergo (Ivanova and Ivanov, 2015), it is still an important option for 
independent hotels. The literature outlines a variety of factors that are taken into consideration by hotel decision makers when choosing to affiliate. For example by Quintas (2006) suggests that the nature and quality of the technology provided by the consortium, access to online platforms for updating data, performance evaluation software, sales force opportunities, and the quality standards of the facilities and services provided to the members of the consortia are important considerations. Carlbäck (2012) identified other factors that influence the decision to affiliate, including: (1) sales and marketing advantages, (2) loyalty cards, (3) increases in efficiency, (4) central purchasing, (5) social media, and (6) control of management and finances. His research demonstrated that the most important factors when considering affiliation were sales, loyalty card, know how, and brand value. Increased efficiency, management control, finance and marketing were considered less important in comparison. Other research by Miguel's (2001), suggests that independent hotels choose to affiliate to obtain access to global booking systems, probability of increased sales through a variety of sales structures, access to new markets, as well as competitive advantage, and enhanced budgeting ability.

Interestingly, the literature reveals a bit of a debate as it relates to the importance of marketing in the affiliation decision-making process. For example, Carlbäck (2012) and Holverson and Revaz (2006) conclude that marketing services are considered less important in the decision-making process. In contrast, Miguel's (2001) research found that marketing services are considered an important consideration. Indeed, this finding may be explained by the fact that marketing can now more easily be undertaken independently by hotels without the need for affiliation.

\section{Cultural aspects of business decision-making}

The decision to remain independent or affiliate is influenced by many economic factors; however, the literature reveals that cultural aspects also influence business decision making. While historically, this has been an understudied area in the hospitality literature, one of the more interesting and recent developments is the focus on thought and behavioral aspects associated with various cultures in the tourism and hospitality workplace (Mattila, 2019). Some of the most extensive and influential research undertaken on the influence of culture in the workplace is that of Geert Hofstede (1980, 1983, 1984, 1991). In the following section, we explore the most relevant aspects of
Hofstede's cultural dimensions research, as it relates to explaining some of the findings of this study.

Hofstede's cultural dimensions. Hofstede's (1984) work examines cultural differences among the inhabitants of more than 50 countries from around the world, particularly as it relates to how such differences affect management planning techniques. Although there are many definitions of culture, Hofstede's (1984) is one that is often cited. Specifically, he defines culture as the "collective programming of the mind which distinguishes the members of one group or society from those of another" (p. 82). It results in patterns of thinking that parents pass along to their children, teachers pass along to their students, friends pass along to their friends, leaders pass along to their followers, and followers pass along to their leaders (Hofstede, 1984). Hofstede adds that aspects of culture reside in people's minds, and are reflected in the "meanings," that individuals then attach to various aspects of their lives. This includes what they view as good and evil, true and false, and or beautiful and ugly (p. 82). While Hofstede states that collective patterns of thinking become imbedded within institutions and the tangible products produced by the society, he clarifies that not all members of a society are programmed in exactly the same manner. Rather, there are differences amongst individuals and differences amongst sub-groups of individuals

Hofstede (1984) contends that business management within a society is restrained by cultural aspects specific to that society. Specifically, business managers are not able to effectively manage without a deep level of understanding of the values, beliefs, and expressions that are held by the individuals within the various cultures. It is these aspects (values, beliefs and expressions) that then, in turn, affect management activities, such as planning. In order to understand cultural differences as it relates to business management, Hofstede (1980, 1983) studied manifestations of culture (i.e. values) at a large multinational business (IBM) with subsidiaries and employees in 67 countries from 1967 through to approximately 1973 . He analyzed the results of a pen and paper survey administered to employees from 50 subsidiary companies. Employees' answered 32 values-based questions. Answers were compared within and across countries based upon similarities within their various employment positions/occupations. The results led to the development of four dimensions (individualism versus collectivism; large versus small power distance; strong versus weak uncertainty avoidance; masculinity versus femininity).

In subsequent research Hofstede added two more dimensions, for a total of six dimensions. The first of 
these later additions is long- versus short-term orientation which was added in 1991 (Hofstede, 1991): the second addition is the indulgence versus restraint dimension in 2010 (see Hofstede-insights.com). In 2017, Hofstede operationalized his research on cultural dimensions into a consulting business known as Hofstede Insights, providing tools (e.g. country profiles), training, facilitation, and certification programs for organizations (see https://www.hofstede-insights. com/product/compare-countries/). In the following paragraphs, we describe the Hofstede dimensions that are of most relevance and assist in explaining some of the findings of our research: individualism versus collectivism and strong versus weak uncertainty avoidance.

Individualism versus collectivism. The individualism versus collectivism dimension is characterized by a society's preference toward valuing a "loosely knit" (individualistic) society or one that is more "tightly knit" (collectivist) (Hofstede, 1984: 83). In an individualistic society, individuals take care of themselves and their immediate families and there is less interdependence amongst individuals. In contrast, individuals within a collectivist society look to their "relatives, clan, or other in-group" to take care of them. In a collectivist society there is more interdependence amongst individuals. In exchange, individuals within a collectivist society then offer unquestioning loyalty (p. 83). As Hofstede states, it is the difference between the self-concept of "I" or "we" (1984: 83).

Strong versus weak uncertainty avoidance. The second dimension we examine is strong versus weak uncertainty avoidance. This dimension is characterized by the degree to which individuals within "a society feel uncomfortable with uncertainty and ambiguity" (Hofstede, 1984: 83). A society that demonstrates a preponderance to avoiding uncertainty, values institutions that protect conformity. Individuals within such a society value adherence to codes of belief and specific conforming behaviors. They are also intolerant of individuals who are different and or who have different ideas. In contrast, weak uncertainty avoidance societies are more relaxed and open to differences amongst individuals and their ideas. Individuals within such a society believe that how one behaves is more important than adherence to a set of conformist principles. One of the most important aspects of this dimension relates to the future. Within a weak uncertainty avoidance society, individuals believe they can control the future, whereas those from a strong uncertainty avoidance society believe that they have no control over the future. As Hofstede (1984) observes, this has implications for how individuals within each type of society, weak or strong uncertainty avoidance, build their institutions and organizations (p. 84).

\section{Methodology}

\section{Introduction}

This study employed a case study approach, utilizing quantitative methods to gather and analyze the data to address the research objectives, as described earlier. In the following paragraphs we detail the data collection instrument, the sample, and the procedures utilized to collect and analyze the data.

\section{Development of the data collection instrument}

Carlbäck's (2016: 391) research served as the foundation for the creation of the data collection tool. The purpose of employing this tool was to identify and rank the importance of the decision-making factors in choosing independence or affiliation, and, to examine the perceived benefits and costs associated with remaining independent versus affiliation. However, based upon feedback received during the piloting stage of the research, changes were made to wording of the importance factors for the questionnaire. These changes were made for translation and relevancy purposes. The final importance factors chosen for assessing the importance of independence were: freedom; independence; control over decisions, shorter decision making; better exploitation of internal resources; and, absence of fees or royalties. The final factors chosen for assessing the importance of affiliation were: increased efficiency; loss of control over management; commercial synergies; more aggressive marketing; loyalty cards; brand value; knowledge sharing; cost sharing; increased sales.

As part of the survey development, a pilot study was undertaken, which included seven $(n=7)$ face-to-face interviews between October and December 2013 with hotel managers and decision-makers of small hotels and hotel chains from Lisbon, Portugal. The purpose of the pilot study was to gather expert opinions on the development of the survey and to validate the key concepts within the survey tool. The pilot interviews ranged from one to two hours in length and adhered to the following procedures: (i) each interview was recorded with the interviewee's permission; (ii) the interviewer asked ten open questions to evaluate the perceptions of the interviewees and the level of knowledge about the subject to be discussed; (iii) the interviews were transcribed and analyzed by the lead researcher. The next step involved sending the pilot study survey to hospitality experts (professionals who 
had worked in the hospitality industry for 15 or more years) $(n=5)$. Individuals from both stages reviewed the contents and gave their opinions on how to improve the survey. As noted, these opinions resulted in minor modifications to Carlbäck's original questionnaire. The final survey was comprised of 25 open and closed-ended questions, in two parts (see online Appendix 1).

\section{Population}

Between January and October 2016, the target population of four- and five-star hotels in Portugal was identified. The inclusion criteria were that the hotels were located in a Portuguese territory, continent, or island. Exclusion criteria were as follows: (a) campsites, (b) hotels-apartments; (c) settlements; (d) tourist apartments, and (e) pensions. The identification of the population was drawn from three different databases: (1) National Register of Tourist Enterprises RNET; (2) the directory of the Portuguese Hotel \& Travel Guide, whose database is powered by information from Turismo de Portugal, Portuguese Association of Hotels (AHP) and the Association of Portuguese Hotels Directors (ADHP); (3) the research project 'Accommodation of the Future' promoted by the Portuguese Association of Hospitality, Restauration and Similar (AHRESP) along with the assistance of Idtour (a Portuguese-based tourism consultant).

Overall, 688 hotels of four and five stars in Portugal were identified with a total offer of 76,543 rooms. Of this sum, 568 hotels were four stars (constituting an offer of 52,166 rooms) and 120 hotels were five stars (with an offer of 14,662 rooms). Within this characterization of four and five stars, two further distinctions were made: size (small and large) and independent affiliation (see Table 1). The UNWTO's (1997) definition of a small hotel was utilized. Specifically, it describes a small hotel as encompassing a property with less than 50 hotel rooms, employing less than 10 employees, and often located in peripheral locations. Therefore, a large hotel was defined as having 50 or more hotel rooms for the purposes of this study. The survey was subsequently e-mailed through the survey platform available at surveymonkey.com. Data collection took place between October 2016 and March 2017.

\section{Response rate}

Overall, 373 questionnaires were returned. Of these, 46 were excluded from the data analysis (26 were duplicates, 20 did not answer a minimum of $50 \%$ of the questions). Consequently, a total of 327 valid
Table 1. Characteristics of hotel properties.

\begin{tabular}{|c|c|c|}
\hline & $\mathrm{n}$ & $\%$ \\
\hline \multicolumn{3}{|l|}{ Type of hotel } \\
\hline Independent & 139 & 42.5 \\
\hline Affiliated & 188 & 57.5 \\
\hline Total & 327 & 100 \\
\hline \multicolumn{3}{|l|}{ Hotel size } \\
\hline Small ${ }^{b}$ & 114 & 34.9 \\
\hline Large $^{c}$ & 213 & 65.1 \\
\hline Total & 327 & 100 \\
\hline \multicolumn{3}{|l|}{ Hotel rating } \\
\hline 4 stars & 228 & 69.7 \\
\hline 5 stars & 99 & 30.3 \\
\hline Total & 327 & 100 \\
\hline \multicolumn{3}{|l|}{ District } \\
\hline Aveiro & 9 & 2.8 \\
\hline Beja & 1 & 0.3 \\
\hline Braga & 9 & 2.8 \\
\hline Castelo Branco & 7 & 2.1 \\
\hline Coimbra & 7 & 2.1 \\
\hline Évora & 11 & 3.4 \\
\hline Faro & 50 & 15.3 \\
\hline Guarda & 5 & 1.5 \\
\hline Leiria & 11 & 3.4 \\
\hline Lisboa & 87 & 26.3 \\
\hline Portalegre & 7 & 2.1 \\
\hline Porto & 35 & 10.7 \\
\hline Santarém & 8 & 2.4 \\
\hline Setúbal & 9 & 2.8 \\
\hline Viana do Castelo & 12 & 3.7 \\
\hline Vila Real & 9 & 2.8 \\
\hline Viseu & 11 & 3.4 \\
\hline Região Autonoma dos Açores & 13 & 4 \\
\hline Região Autonoma da Madeira & 26 & 8 \\
\hline Total & 327 & 99.9 \\
\hline \multicolumn{3}{|l|}{ Environment } \\
\hline Urban & 136 & 31.6 \\
\hline Mountains & 26 & 5.3 \\
\hline Rural & 62 & 21.1 \\
\hline Beach & 73 & 28.1 \\
\hline Other ${ }^{a}$ & 30 & 13.9 \\
\hline Total & 327 & 100 \\
\hline \multicolumn{3}{|l|}{ Segment } \\
\hline Luxury market & 83 & 25.4 \\
\hline Family vacation & 88 & 26.9 \\
\hline Romantic escapes & 29 & 8.9 \\
\hline All inclusive & 19 & 5.8 \\
\hline Corporate & 46 & 14.1 \\
\hline Other & 62 & 19 \\
\hline Total & 327 & 100.1 \\
\hline
\end{tabular}

ancluded: golf, golf resort, nature, charm, historic, health and well-being, city resort, country house, design, termal, boutique.

${ }^{\text {b }}$ Small hotel: $\leq 50$ rooms; $\leq 10$ employees.

'Large hotel: $>50$ rooms; $>10$ employees. 
questionnaires were obtained and analyzed, representing an overall response rate of $47.5 \%$.

\section{Validation of the questionnaire}

The validation of the questionnaire was performed using Cronbach's Alpha internal consistency analysis. Cronbach's alpha score was found to be acceptable (0.854) according to literature recommendations. To test the hypotheses, a set of statistical analyzes were conducted, including: T-test for paired samples; t-test for independent samples; Chi-square test; and, standard deviation. Data analysis was conducted using the IBM SPSS 19.

\section{Application of Hofstede's country profiles tool}

While the questionnaire was employed to collect data, we also utilized the country profiles tool, available through Hofstede's Insights website, to assist in explaining some of the results of this study (see https://www. hofstede-insights.com/product/compare-countries/).

This free, online tool, enables the user to select and compare countries on the six values-based dimensions (see the section Hofstede's cultural dimensions). Each country is scored individually on each of the six dimensions. For our purposes, we examined two of the six dimensions for Portugal and Sweden (as it relates to Carlbäck's research) that we were most relevant in explaining some of our findings: uncertainty avoidance and collectivism (see the section Discussion).

\section{Results}

For these purposes we focus our findings in the following areas: (1) the characteristics of the hotel property, and (2) the findings of two key research questions. The first question (see Q12, online Appendix 1) asked: How important are the following factors in motivating a hotel to choose independence over a hotel consortium? The second question (see Q13, online Appendix 1) asked: How important are the following factors in motivating a hotel to choose affiliation over independence?

The first question sought to determine the level of importance of the various factors that motivate hotel decision makers (affiliated and independent) to remain independent. The second question sought to identify the level of importance of the various factors that motivate hotel decision makers (affiliated and independent) to affiliate with a consortium. Both questions utilized a five-point Likert scale. The higher the numeric ranking, the great the importance:
$1=$ not at all important $; 2=a$ little important; $3=$ important $; 4=$ very important $; 5=$ most important . There was also an option for participants to indicate Do not know/no response.

\section{Characteristics of hotel properties}

In order to assess the geographic distribution, environment, size (number of rooms and number of employees), environment, and market segments of the hotel properties, descriptive analysis of frequency of different levels of response was carried out.

Overall, the sample of 327 hotels in composed of affiliated hotels $(n=188)$ and independent hotels $(\mathrm{n}=139)$. Concerning the size, the sample was composed of small hotels $(n=114 ; 34.9 \%)$ and large hotels $(\mathrm{n}=213 ; 65.1 \%)$. The majority of hotels that participated in this study were four stars $(n=228$; $68.8 \%)$, and five-star hotels $(\mathrm{n}=99 ; 30.3 \%)$, of all districts in Portugal, except Bragança. ${ }^{1}$ The three districts with the highest number of participating hotels include Lisbon $(\mathrm{n}=87 ; 26.3 \%)$, followed by Faro $(\mathrm{n}=50 ; 15.3 \%)$ and Porto $(\mathrm{n}=35 ; 10.7 \%)$. Concerning the environment (as described by Ivanova and Ivanov, 2015) the hotel respondents were mostly urban $(n=136 ; 31.6 \%)$ and the most popular segment represented by the hotels was family vacations $(n=88 ; 26.9 \%)$, followed by the luxury market $(n=83 ; 25.4 \%)$. Table 1 provides more detail regarding the respondent characteristics.

\section{Characteristics of respondents}

The respondents were mainly general managers $(\mathrm{n}=208 ; 63.6 \%)$, followed by commercial directors $(\mathrm{n}=83 ; 25.4 \%)$. More than half $(52 \%)$ of the respondents reported that they had been with their current employer less than a year, $20.6 \%$ had worked less than two years, $16.1 \%$ had worked less

Table 2. Characteristics of hotel decision-makers.

\begin{tabular}{lll}
\hline Characteristics of decision-makers & $\mathrm{n}$ & $\%$ \\
\hline Position & & \\
Owner & 22 & 6.7 \\
General managers & 208 & 63.6 \\
Marketing director & 14 & 4.3 \\
Commercial director & 83 & 25.4 \\
Total & 327 & 100 \\
Length of service with current hotel & & \\
Less than one year & 170 & 52.0 \\
One year & 69 & 20.6 \\
Two years & 52 & 16.1 \\
Three years or more & 36 & 11.3 \\
Total & 327 & 100 \\
\hline
\end{tabular}


Table 3. Ranking of importance factors associated with independence (independent hoteliers' perception, $n=139$ ).

\begin{tabular}{|c|c|c|c|c|c|c|}
\hline & Freedom & Independence & $\begin{array}{l}\text { Control } \\
\text { over } \\
\text { decision }\end{array}$ & $\begin{array}{l}\text { Shorter } \\
\text { decision- } \\
\text { making }\end{array}$ & $\begin{array}{l}\text { Better exploitation } \\
\text { of internal resources }\end{array}$ & $\begin{array}{l}\text { Absence of } \\
\text { fees or } \\
\text { royalties }\end{array}$ \\
\hline Not at all important & 1.7 & 2.5 & 0.8 & 0.8 & 1.7 & 0.8 \\
\hline Little important & 7.5 & 6.7 & 2.5 & 4.2 & 11.3 & 8.4 \\
\hline Sum & 9.2 & 9.2 & 3.3 & 5 & 13 & 9.2 \\
\hline Important & 30.8 & 28.3 & 14.3 & 16.1 & 22.6 & 22.7 \\
\hline Very important & 36.7 & 35.8 & 37 & 37.3 & 37.4 & 26.9 \\
\hline Most important & 23.3 & 26.7 & 45.4 & 41.5 & 27 & 41.2 \\
\hline Sum $^{a}$ & 60 & 62.5 & 82.4 & 78.8 & 64.4 & 68.1 \\
\hline
\end{tabular}

aWe have included data as it relates to "Important" for the benefit of the reader. It is not included in the sums reported here.

Table 4. Ranking of importance factors associated with independence (affiliated hoteliers' perception, $n=188$ ).

\begin{tabular}{|c|c|c|c|c|c|c|}
\hline & Freedom & Independence & $\begin{array}{l}\text { Control } \\
\text { over decision }\end{array}$ & $\begin{array}{l}\text { Shorter } \\
\text { decision- } \\
\text { making }\end{array}$ & $\begin{array}{l}\text { Better exploitation } \\
\text { of internal resources }\end{array}$ & $\begin{array}{l}\text { Absence of } \\
\text { fees or } \\
\text { royalties }\end{array}$ \\
\hline Not at all important & 5.8 & 7.1 & 3.2 & 4.5 & 7.1 & 5.2 \\
\hline Little important & 24 & 19.9 & 9.6 & 9.1 & 21.2 & 7.1 \\
\hline Sum & 29.8 & 27 & 12.8 & 13.6 & 28.3 & 12.3 \\
\hline Important & 31.2 & 30.8 & 29.3 & 22.7 & 25.6 & 25.8 \\
\hline Very important & 28.6 & 29.5 & 28.7 & 34.4 & 28.2 & 27.7 \\
\hline Most important & 10.4 & 12.8 & 29.3 & 29.2 & 17.9 & 34.2 \\
\hline Sum ${ }^{a}$ & 39 & 42.3 & 58 & 63.6 & 46.1 & 61.9 \\
\hline
\end{tabular}

aWe have included data as it relates to "Important" for the benefit of the reader. It is not included in the sums reported here.

than three years, while $11.3 \%$ had worked for three or more years (see Table 2).

\section{Importance of factors associated with remaining independent}

A descriptive analysis of the frequency of response levels was carried out. For the purposes of our findings here, we combine the categories "very" and "most important," as well as "not at all" and "a little important."

Importance of factors associated with independence (independent hoteliers' perception, $n=139$ ). Overall, control over decision-making $(82.4 \%)$ and shorter decision-making $(78.8 \%)$ were the two highest ranked factors stated by independent hotels as being very and most important. Absence of fees or royalties $(68.1 \%)$ and better exploitation of resources $(64.4 \%)$ were also considered very and most important by independent hoteliers. Better exploitation of internal resources $(13 \%)$, freedom $(9.2 \%)$, independence $(9.2 \%)$, and absence of fees or royalties $(9.2 \%)$ were the lowest ranked importance factors by independent hotels as being not at all important and a little important (see Table 3).

Importance of factors associated with independence (affiliated hoteliers' perception, $n=188$ ). Similarly, we sought to understand how affiliated hoteliers perceived the importance of factors related to remaining independent. Again, we combine the categories "very" and "most important," as well as "not at all" and "a little important." The highest ranked importance factors stated by affiliated hotels related to remaining independent were short decision-making $(63.6 \%)$ and the absence of fees or royalties $(61.9 \%)$. For affiliated hotels, freedom (29.8), better exploitation of internal resources $(28.3 \%)$, and independence $(27.0 \%)$, were the most cited factors as being not at all important and a little important (see Table 4).

Factors associated with independence laffiliated and independent hoteliers' perception combined, $n=327$ ). In this section, we present the aggregated results for both affiliated and independent hoteliers' ranking of the factors associated with remaining independent. Overall, the four highest ranked factors as it 
relates to the combined responses to most important and very important were short decision making (70.1\%), control over decision $(68.4 \%)$, and absence of fees or royalties $(64.4 \%)$, which was ranked the same as exploitation of internal resources (64.4\%). At the other end of the Likert scale, the two least important factors as it relates to the combined responses to not at all important and a little important were freedom $(20.7 \%)$ and independence $(19 \%)$ (see Table 5).

In order to ascertain the differences in the perceptions of the decision-makers of independent hotels and affiliated hotels regarding the importance of the factors that contribute to staying independent, a descriptive analysis of the frequency of different response levels was carried out utilizing a Chi-square test. Overall, the analysis reveals statistically significant differences in the perception of independent versus affiliated hotel decision makers in relation to the following independence factors: freedom $\left(\chi^{2}=21.487\right.$, $\mathrm{p}<0.001)$; independence $\left(\chi^{2}=18.772, \mathrm{p}=0.001\right)$; control over decision $\left(\chi^{2}=18.757, \mathrm{p}=0.001\right)$; shorter decision-making $\left(\chi^{2}=9.478, \mathrm{p}=0.050\right)$; and, better exploitation of internal resources $\left(\chi^{2}=11.632\right.$, $\mathrm{p}=0.020$ ). In other words, independent hotel decision makers place statistically more value on freedom, independence, control over decision-making, shorter decision making, and better exploitation of internal resources than affiliated hotel decision makers.

\section{Importance of factors associated with affiliation}

A descriptive analysis of the frequency in response levels was carried out and is reported in the following paragraph.

Importance of factors associated with affiliation (independent hoteliers' perceptions, $n=139$ ). The three top ranked factors considered most and very important by independent hotels as it relates to affiliating were increased sales (93.3\%), more aggressive marketing $(86.6 \%)$, and commercial synergies $(85.8 \%)$. The three highest ranked factors considered a little and not at all important by independent hotels as it relates to affiliating were loyalty card $(21.6 \%)$, loss of control over management $(12.6 \%)$, and increased efficiency (11\%) (see Table 6).

Importance of factors associated with affiliation (affiliated hoteliers' perceptions; $n=188$ ). The four highest ranked factors considered most and

Table 5. Aggregated ranking of importance factors related to independence (affiliated and independent; $\mathrm{n}=327$ ).

\begin{tabular}{|c|c|c|c|c|c|c|}
\hline & Freedom & Independence & $\begin{array}{l}\text { Control over } \\
\text { decision }\end{array}$ & $\begin{array}{l}\text { Shorter } \\
\text { decision- } \\
\text { making }\end{array}$ & $\begin{array}{l}\text { Better exploitation } \\
\text { of internal resources }\end{array}$ & $\begin{array}{l}\text { Absence of } \\
\text { fees or } \\
\text { royalties }\end{array}$ \\
\hline Not at all important & 4 & 5 & 2.2 & 2.9 & 3.3 & 3.3 \\
\hline Little important & 16.7 & 14 & 6.5 & 6.9 & 7.6 & 7.6 \\
\hline Sum & 20.7 & 19 & 8.7 & 9.8 & 10.9 & 10.9 \\
\hline Important & 31.2 & 29.9 & 23 & 20.1 & 24.7 & 24.7 \\
\hline Very important & 31.9 & 32.4 & 32.4 & 35.8 & 27.3 & 27.3 \\
\hline Most important & 16.3 & 18.7 & 36 & 34.3 & 37.1 & 37.1 \\
\hline Sum $^{a}$ & 48.2 & 51.1 & 68.4 & 70.1 & 64.4 & 64.4 \\
\hline
\end{tabular}

aWe have included data as it relates to "Important" for the benefit of the reader. It is not included in the sums reported here.

Table 6. Ranking of importance factors associated with affiliation (independent hoteliers' perceptions, $\mathrm{n}=139$ ).

\begin{tabular}{|c|c|c|c|c|c|c|c|c|c|}
\hline & $\begin{array}{l}\text { Increased } \\
\text { efficiency }\end{array}$ & $\begin{array}{l}\text { Loss of } \\
\text { control over } \\
\text { management }\end{array}$ & $\begin{array}{l}\text { Commercial } \\
\text { synergies }\end{array}$ & $\begin{array}{l}\text { More } \\
\text { aggressive } \\
\text { marketing }\end{array}$ & $\begin{array}{l}\text { Loyalty } \\
\text { card }\end{array}$ & $\begin{array}{l}\text { Brand } \\
\text { value }\end{array}$ & $\begin{array}{l}\text { Knowledge } \\
\text { sharing }\end{array}$ & $\begin{array}{l}\text { Cost } \\
\text { sharing }\end{array}$ & $\begin{array}{l}\text { Increased } \\
\text { sales }\end{array}$ \\
\hline Not at all important & 2.5 & 0 & 0 & 0 & 3.3 & 0.8 & 3.3 & 0.8 & 0 \\
\hline Little important & 8.5 & 12.6 & 2.5 & 5 & 18.3 & 4.2 & 0 & 6.7 & 3.4 \\
\hline Sum & 11 & 12.6 & 2.5 & 5 & 21.6 & 5 & 3.3 & 7.5 & 3.4 \\
\hline Important & 20.3 & 30.3 & 11.7 & 8.3 & 32.5 & 16.7 & 15.8 & 20.8 & 3.4 \\
\hline Very important & 36.4 & 30.3 & 35.8 & 30.8 & 25 & 31.7 & 37.5 & 40.8 & 31.1 \\
\hline Most important & 32.2 & 26.9 & 50 & 55.8 & 20.8 & 46.7 & 43.3 & 30.8 & 62.2 \\
\hline Sum ${ }^{a}$ & 68.6 & 57.2 & 85.8 & 86.6 & 45.8 & 78.4 & 80.8 & 71.6 & 93.3 \\
\hline
\end{tabular}

aWe have included data as it relates to "Important" for the benefit of the reader. It is not included in the sums reported here. 
very important by affiliated hotels as it relates to affiliating were increased sales $(96.9 \%)$, brand value $(91.8 \%)$, and more aggressive marketing (91.2\%), and commercial synergies $(90.1 \%)$. The three highest ranked factors considered of little and not all important by affiliated hoteliers as it relates to affiliating were loss of control over management $(28.4 \%)$, loyalty card $(12.6 \%)$, and cost sharing $(3.7 \%)$ (see Table 7).

Ranking of importance factors associated with affiliation laffiliated and independence hoteliers' perception; $n=327$ ). The four highest ranked factors most often considered as very and most important as it relates to choosing to affiliate, by affiliated and independent hotels were: increased sales $(93.2 \%)$ followed by more aggressive marketing (89.2\%), commercial synergies $(88.2 \%)$, and knowledge sharing $(86.1 \%)$. The two highest ranked factors considered as little important and not at all important as it relates to choosing to affiliate, by affiliated and independent hotels, were loss of control over management $(21.5 \%)$ and loyalty card $(16.6 \%)$ (see Table 8 ).

In order to ascertain the differences in the perceptions of the decision-makers of independent hotels and affiliated hotels regarding the importance of the factors that contribute to affiliating, a descriptive analysis of the frequency of different response levels was carried out utilizing a Chi-square test. The results of this analysis reveal that there were statistically significant differences in the perception of small versus large affiliated hotel decision makers in relation to the following factors: brand value; $\left(\chi^{2}=8.109, \mathrm{p}<0.044\right)$; and, loyalty card $\left(\chi^{2}=11.609, \mathrm{p}<0.009\right)$. When deciding whether to affiliate, the presence of a loyalty card system was a very important factor for $73.5 \%$ of large hotels, while $26.5 \%$ of small hotels felt it was very important. Brand value is an important factor for $29.6 \%$ of large hotels, and $29.6 \%$ for small hotels.

\section{Discussion}

In the following sections we present some of the key findings. Specifically, we focus our discussion in the following areas: importance of factors associated with remaining independent from the perspective of both affiliated and independent hoteliers; and importance of factors associated with affiliation from the perspective of both affiliated and independent hoteliers. We compare and contrast the findings of this research to

Table 7. Ranking of importance factors associated with affiliation (affiliated hoteliers' perceptions, $n=188$ ).

\begin{tabular}{|c|c|c|c|c|c|c|c|c|c|}
\hline & $\begin{array}{l}\text { Increased } \\
\text { efficiency }\end{array}$ & $\begin{array}{l}\text { Loss of } \\
\text { control over } \\
\text { management }\end{array}$ & $\begin{array}{l}\text { Commercial } \\
\text { synergies }\end{array}$ & $\begin{array}{l}\text { More } \\
\text { aggressive } \\
\text { marketing }\end{array}$ & $\begin{array}{l}\text { Loyalty } \\
\text { card }\end{array}$ & $\begin{array}{l}\text { Brand } \\
\text { value }\end{array}$ & $\begin{array}{l}\text { Knowledge } \\
\text { sharing }\end{array}$ & $\begin{array}{l}\text { Cost } \\
\text { sharing }\end{array}$ & $\begin{array}{l}\text { Increased } \\
\text { sales }\end{array}$ \\
\hline Not at all important & 1.3 & 5.2 & 1.2 & 1.9 & 3.8 & 0.6 & 0 & 0.6 & 0.6 \\
\hline Little important & 1.9 & 23.2 & 0.6 & 0.6 & 8.8 & 0 & 0 & 3.1 & 0 \\
\hline Sum & 3.2 & 28.4 & 1.8 & 2.5 & 12.6 & 0.6 & 0 & 3.7 & 0.6 \\
\hline Important & 17.1 & 34.8 & 8.1 & 6.3 & 24.5 & 7.5 & 9.9 & 28.7 & 2.5 \\
\hline Very important & 39.9 & 18.7 & 32.3 & 34 & 33.3 & 27 & 45.3 & 31.3 & 25.6 \\
\hline Most important & 39.9 & 18.1 & 57.8 & 57.2 & 29.6 & 64.8 & 44.7 & 36.6 & 71.3 \\
\hline Sum $^{a}$ & 79.8 & 36.8 & 90.1 & 91.2 & 62.9 & 91.8 & 90 & 67.9 & 96.9 \\
\hline
\end{tabular}

"We have included data as it relates to "Important" for the benefit of the reader. It is not included in the sums reported here.

Table 8. Aggregated ranking of importance factors related to affiliation (affiliated and independent; $\mathrm{n}=327$ ).

\begin{tabular}{|c|c|c|c|c|c|c|c|c|c|}
\hline & $\begin{array}{l}\text { Increased } \\
\text { efficiency }\end{array}$ & $\begin{array}{l}\text { Loss of } \\
\text { control } \\
\text { over } \\
\text { management }\end{array}$ & $\begin{array}{l}\text { Commercial } \\
\text { synergies }\end{array}$ & $\begin{array}{l}\text { More } \\
\text { aggressive } \\
\text { marketing }\end{array}$ & $\begin{array}{l}\text { Loyalty } \\
\text { card }\end{array}$ & $\begin{array}{l}\text { Brand } \\
\text { value }\end{array}$ & $\begin{array}{l}\text { Knowledge } \\
\text { sharing }\end{array}$ & $\begin{array}{l}\text { Cost } \\
\text { sharing }\end{array}$ & $\begin{array}{l}\text { Increased } \\
\text { sales }\end{array}$ \\
\hline Not at all important & 1.8 & 2.9 & 0.7 & 1.1 & 3.6 & 0.7 & 0 & 0.7 & 0.7 \\
\hline Little important & 4.7 & 18.6 & 1.4 & 2.5 & 12.9 & 1.8 & 1.4 & 4.6 & 1.4 \\
\hline Sum & 6.5 & 21.5 & 2.1 & 3.6 & 16.5 & 2.5 & 1.4 & 5.3 & 2.1 \\
\hline Important & 18.5 & 32.8 & 9.6 & 7.2 & 28 & 11.5 & 12.5 & 25.4 & 4.6 \\
\hline Very important & 38.4 & 23.7 & 33.8 & 32.6 & 29.7 & 19 & 42 & 35.4 & 28.6 \\
\hline Most important & 36.6 & 21.9 & 54.4 & 56.6 & 25.8 & 57 & 44.1 & 33.9 & 64.6 \\
\hline Sum ${ }^{a}$ & 75 & 45.6 & 88.2 & 89.2 & 55.5 & 76 & 86.1 & 69.3 & 93.2 \\
\hline
\end{tabular}

"We have included data as it relates to "Important" for the benefit of the reader. It is not included in the sums reported here. 
past studies. In order to explain some of the more unique findings of this research and the possible link to the influence of culture in decision making, we link our findings to the research of Hofstede (1980, 1983, 1984, 1991), Hofstede et al. (2010), and Minkov and Hofstede (2012).

\section{Importance of factors associated with remaining independent}

The results of this study indicate that the three factors considered most important in remaining independent, by independent hoteliers, are: control over decisions; shorter-decision making; and the absence of fees or royalties. Interestingly, affiliated hoteliers also ranked shorter decision making, the absence of fees or royalties, and control over decision making as the three most important factors for remaining independent. In other words, both independent and affiliated hoteliers recognize the importance of these three factors associated with independence. These findings reflect the findings of Carlbäck's (2012) study that demonstrated Swedish independent hoteliers valued control over decision-making and the lack of fees and royalties. Holverson and Revaz (2006) and Miguel (2001) had a similar finding to this study regarding the importance of fees and royalties. It is also in line with the difficulties referred to by Quintas (2006) and is not a surprising concern for hotel decision makers.

One of the more interesting findings is related to the importance ranking of the freedom and independence factors, associated with independence. For example, while both independent and affiliated hotels in this study considered freedom and independence important, of the six factors, freedom and independence were ranked fifth and sixth in the combined categories of very important and most importance. This is an interesting finding that could be explained through the application of Hofstede's (1980, 1983, 1984, 1991) research as well as that of Hofstede et al. (2010) and Minkov and Hofstede (2012), as it relates to cultural dimensions.

As indicated in Hofstede's research, Portuguese society has a lower propensity to value individuality when compared to Swedish society. According to the comparison of countries scores, Portugal scores 27 on individualism, while Sweden scores 71 (see https:// www.hofstede-insights.com/product/compare-coun tries/). Countries are scored from one to 100, with scores closer to 100 suggesting a propensity to more highly value individualism. According to Hofstede's (1984) research, the management spirit that prevails in Portugal is collectivism, where individuals value being part of a 'group' in exchange for group loyalty. In contrast, Hofstede's research appears to suggest that Swedish people are individualist $($ score $=71$ ) and value independence. Indeed, Carlbäck's (2012) research on Swedish hotels, demonstrated decisionmakers' preference to remain independent. In other words, the fact that respondents in this study ranked independence and freedom as important, but to a lesser degree than other factors may be explained through the application of Hofstede's cultural dimensions research. Culturally, independence and freedom appear to be less valued in Portuguese culture than in Swedish culture, and this is appears to be reflected in the findings of this study as it relates to four- and fivestar hoteliers in Portugal.

\section{Importance of factors associated with affiliation}

Not surprisingly, both affiliated and independent hoteliers recognized the potential for increased sales as a result of affiliation, as demonstrated by the fact that they both ranked this as the most important factor associated with affiliation. Perhaps what is surprising is that independent hotels recognized this potential to almost the same extent that the affiliated hotels did. This finding suggests that despite this potential for increased sales, independent hotels saw other benefits in remaining independent (e.g. control over decision making, shorter-decision making, and the absence of fees or royalties). Indeed, it appears that the benefits of remaining independent, outweigh the potential for increased sales.

Another similar finding amongst affiliated and independent hoteliers, when considering affiliation, relates to loyalty cards. Loyalty cards are a tool used for companies to acquire and to retain new customers (Mauri, 2003). They also gather information on the customer's spending, which is relayed back to the company every time the customer uses the card. Companies develop a loyalty strategy, such as loyalty cards, in order to reward regular customers. Collected points can be exchanged by customers for products, services, discounts or upgrades. Overall, both independent and affiliated hoteliers ranked loyalty cards as important, but less so in comparison to most of the other factors. For example, loyalty cards were considered the least important by independent hoteliers and the second least important by affiliated hoteliers. This finding stands in contrast to Carlbäck's (2012) study in Sweden that indicated high value associated with the presence of a loyalty card system. This difference may be explained by the lack of tradition related to loyalty cards in Portugal.

One of the more interesting findings from this research relates to the apparent lack of importance (by both affiliated and independent hoteliers) 
associated with the loss of control over management, which is considered a factor associated with affiliation. For independent hoteliers, it was ranked the second least important (behind loyalty cards), while for affiliated hoteliers it was ranked as the least important factor. To present a possible explanation for this finding, we again turn to Hofstede's (1984) research on cultural dimensions particularly as it relates to the two dimensions: uncertainty avoidance and collectivism. As discussed earlier, Hofstede (1984) defines uncertainty avoidance as the comfort level of a society as it relates to uncertainty and ambiguity. Portugal scores very high (99) in uncertainty avoidance. As noted by Hofstede (1984), societies high in uncertainty avoidance tend to value institutions that protect conformity.

The fact that respondents, Portuguese hoteliers, associated the potential loss of control over management as being of little importance appears to gel with Hofstede's theory as it relates to uncertainty avoidance and the high score attributed to Portugal. Specifically, one could assume that affiliation means a certain level of loss of control over management; however, affiliation would also result in the added benefit of management expertise from the consortium. This could then result in a decrease in management uncertainty. In other words, there may be a higher level of certainty as it relates to drawing from the management expertise from others within the consortium and this then overrides the loss of control over management, associated with affiliation. This may explain why the respondents in this study were less concerned with the loss of control over management often associated with affiliation.

\section{Limitations}

There are limitations, beyond the case study approach used in this research, specifically as it relates to the data collection process. For example, the Portuguese hotel industry entered a period of restructuring during the data collection time period. As a result, several independent hotels and also some hotel groups went into bankruptcy. In other cases, national hotel chains were sold to foreign investors, while other hotels were involved in mergers. Overall, we believe this situation led to a lower response rate than might have been expected in more settled times, as many decisionmakers were likely too busy dealing with important issues related to this situation, to prioritize the completion of our questionnaire.

In a related limitation, the restructuring resulted in significant changes in human resources, which, combined with regular human resource turnover, meant that the data collection phase was challenging and time consuming. In some cases, a respondent who began the questionnaire moved to another hotel and consequently did not complete and/return the survey. In such cases, we were required to resend a new questionnaire to the new manager of the hotel, in order to maintain consistency. Similarly, we believe that this situation negatively affected the response rate.

\section{Conclusion}

Overall, this study indicates that the three factors considered most important in remaining independent, by both independent and affiliated hoteliers, are control over decisions, shorter decision making, and the absence of fees or royalties. Not surprisingly, both affiliated and independent hoteliers recognized the potential for increased sales as a result of affiliation. While both affiliated and independent hoteliers saw loyalty cards to be less important factors in the decision to affiliate, brand value was considered more important by affiliated hoteliers than independent hoteliers.

Some of these findings were explained in terms of cultural nuances specific to Portugal. Overall, the propensity towards Portuguese collectivism and strong uncertainty avoidance may have influenced the findings of this study in ways described earlier. While these findings have important implications for Portuguese hoteliers (as outlined below), it would be valuable to repeat this research in other geographic areas for enhanced understanding. This is particularly so as it relates to how these factors may be similar and dissimilar based upon the unique geographic, political, economic, environmental, and social characteristics of a country or specific region, and the cultural elements related to the decision-making process of hoteliers around the world.

Finally, we conclude by drawing attention to the more important implications of this study for both affiliated and independent hoteliers. For example, as it relates to consortiums seeking to solicit independent Portuguese hoteliers to join their ranks, it may be beneficial to emphasize the benefits of collaborative marketing associated with affiliation. This is particularly so as it relates to the potential for increased sales. Consortiums may also want to consider increasing the level of flexibility in their fees and royalty structures, as well as permitting more independent decision making as a strategy to draw in more independent hoteliers. Overall, these findings may prove valuable to consortia decision makers such that they may better understand what factors Portuguese hotel decision-makers consider most important when considering the affiliation process, and the cultural nuances that influence their decision-making processes. Similarly, these findings have important implications for independent Portuguese hoteliers, particularly as it 
relates to more fully understanding the perceived risks and benefits of remaining independent as opposed to choosing affiliation. This is particularly so as it relates to the benefits associated with being part of a consortium, including the ability to better weather financial turbulence. In a constantly changing business environment, the findings of this study may provide valuable information to both independent and affiliated hotel decision-makers in terms of ensuring their decisionmaking, as well as business and marketing strategies, are aligned for long-term success.

\section{Declaration of Conflicting Interests}

The author(s) declared no potential conflicts of interest with respect to the research, authorship, and/or publication of this article.

\section{Funding}

The author(s) received no financial support for the research, authorship, and/or publication of this article.

\section{Note}

1. Bragança hotels did not supply data for this study.

\section{ORCID iD}

Sofia Almeida (D) https://orcid.org/0000-0003-4561-6776

\section{References}

Akbar YH and Tracogna A (2018) The sharing economy and the future of the hotel industry: Transaction cost theory and platform economics. International fournal of Hospitality Management 71: 91-101.

Almeida ASBA (2018) O fenómeno da coopetição nas redes de hotéis - o caso dos consórcios de marketing hoteleiro. Unpublished doctoral dissertation, University of Lisbon, Portugal. Available at: http://repositorio.ul.pt/h andle/10451/34415 (accessed 10 March 2020).

American Marketing Association (1960) Marketing Definitions: A Glossary of Marketing Terms. Chicago: American Marketing Association.

Andersen A (2000) Boutique hotels an Australian perspective. Available at: www.hotelonline.com/Trends/ Andersen/2001_Boutique Perspective.html (accessed 10 March 2020).

Bardi JA (2003) Hotel Front Office Management. 4th ed. London: John Wiley \& Sons.

Braun R (2013) To brand or not to brand (your hotel). Global Hospitality Group Blog. Available at: www.hospi talitynet.org/opinion/4060100.html (accessed 10 March 2020).

Carlbäck M (2008) Are the chain operations simply with it? Five aspects meal model as a development tool for chain operations/franchise organizations. Fournal of Foodservice 19(1): 74-79.
Carlbäck M (2012) Strategic entrepreneurship in the hotel industry: The role of chain affiliation. Scandinavian Fournal of Hospitality \& Tourism 12(4): 349-372.

Carlbäck M (2016) Independent or Flagged? The Decision to Affiliate to a Chain. The Routledge Handbook of Hotel Chain Management. New York: Routledge, pp. 385-394.

Contractor FJ and Kundu SK (1998) Modal choice in a world of alliance: Analyzing organizational forms in the international hotel sector. Fournal of International Business Studies 29: 325-357.

Freund de Klumbis D (2002) Seeking the ultimate hotel experience. In: XIIe International Leisure and Tourism Symposium ESADE-Fira de Barcelona, Barcelona, Gestión en H, No. 11, May-June 2003, pp. 58-76.

Guttentag DA and Smith SLJ (2017) Assessing Airbnb as a disruptive innovation relative to hotels: Substitution and comparative performance. International fournal of Hospitality Management 64(July): 1-10.

Hofstede G (1980) Culture's Consequences: International Differences in Work-Related Values. Beverly Hills: Sage.

Hofstede G (1983) Dimensions of national cultures in fifty countries and three regions. In: Deregowski JB, Dziurawiec S and Annis RC (eds) Expiscations in Cross-Cultural Psychology. Lisse: Swets \& Zeitlinger, pp. 335-355.

Hofstede G (1984) Cultural dimensions in management and planning. Asia Pacific Fournal of Management 1(2): 81-99.

Hofstede G (1991) Cultures and Organizations: Software of the Mind. London: McGraw-Hill.

Hofstede G, Hofstede GJ and Minkov M (2010) Cultures and Organizations: Software of the Mind. Intercultural Cooperation and Its Importance for Survival. London: McGraw-Hill.

Hoisingtone A (2019) Soft-brand collections: The new norm? Hotel Management. Available at: www.hotelmanagement. net/own/soft-brand-collections-new-norm?fbclid=IwAR3v RbGFMxKmtIZm8ZNCyGP5BT8RL4nsvK2oc_e81fa G162Gz7M9-tntZkE (accessed 10 March 2020).

Holverson S, Holverson K, Mungall A, et al. (2010) The strategic importance of affiliation with lifestyle consortia for small and medium-sized independent hotels. Final report. Lausanne Hospitality Research. Available at: http://publications.ehl.edu/fre/content/download/ .../Final\%20Report\%20.pdf (accessed 10 March 2020).

Holverson S and Revaz F (2006) Perceptions of European independent hoteliers: Hard and soft branding choices. International fournal of Contemporary Hospitality Management 18(5): 398-413.

Ivanova $M$ and Ivanov S (2015) Affiliation to hotel chains: Hotels' perspective. Tourism Management Perspectives 16: 148-162.

Ivanov S and Ivanova M (2016) The Choice of Type of Affiliation to a Chain by the Individual Hotel. The Routledge Handbook of Hotel Chain Management. New York: Routledge.

Ivanova $M$ and Rahimi R (2016) Nature and definition of hotel chain. In: Ivanova M, Ivanov S and Magnini P (eds) The Routledge Handbook of Hotel Chain Management. New York: Routledge, pp. 9-18. 
INE (2010) Estatísticas do Turismo, 2010, Instituo Nacional de Estatísticas. Available at: http://ine.cv/fr/pub licacoes/estatisticas-do-turismo-7/ (accessed $10 \mathrm{March}$ 2020).

INE (2017) Estatísticas do Turismo, 2017, Instituo Nacional de Estatísticas. ISBN | 978-989-25-0447-6. Avaiabe at: https://www.google.com/search?client=safari\&rls=en\&q= $\mathrm{INE}+(2017)+$ Estat $\%$ C3\%ADsticas +do+Turismo, +2017, +Instituo+Nacional+de+Estat $\%$ C3\%ADsticas. +ISBN+ $\% 7 \mathrm{C}+978-989-25-0447-\&$ ie=UTF-8\&oe=UTF-8

Jiang Y and Peng MW (2011) Are family ownership and control in large firms good, bad, or irrelevant? Asia Pacific Fournal of Management 28(1): 15-39.

Koutoula D (2016) Selecting a partner chain by the hotel. In: Ivanova M, Ivanov $\mathrm{S}$ and Magnini VP (eds) The Routledge Handbook of Hotel Chain Management. Routledge Handbooks Online. Available at: www.rout ledgehandbooks.com/doi/10.4324/9781315752532.ch34 (accessed 10 March 2020).

Lawson C (1997) Towards a Competence Theory of the Region. Cambridge: ESRC Centre for Business Research.

Marvel M (2004) Trends in hotel distribution channels. Ehlite Magazine 5: 6-8.

Mattila AS (2019) A commentary on cross-cultural research in hospitality \& tourism inquiry (invited paper for 'luminaries' special issue of International Journal of Hospitality Management). International Fournal of Hospitality Management 76: 10-12.

Mauri C (2003) Card loyalty. A new emerging issue in grocery retailing. Fournal of Retailing and Consumer Services 10(1): 13-25.

Miguel IC (2001) Uma análise do diferencial competitivo de hotéis associados a cadeias hoteleiras internacionais. Dissertação doutoral, Fundação Getúlio Vergas, Rio de Janeiro, Brasil.

Minkov M and Hofstede G (2012) Hofstede's fifth dimension: New evidence from the word values survey. Fournal of Cross-Cultural Psychology 43(1): 3-14.

Morrison A (1998) Small firm co-operative marketing in a peripheral tourism region. International fournal of Contemporary Hospitality Management 10(5): 191-197.

Mulindwa D and Ulu V (2016) Hotel affiliation evaluation: remaining, leaving, or rebranding? In: Ivanova M, Ivanov $S$ and Magnini VP (eds) The Routledge Handbook of Hotel Chain Managemnt. UK: Rutledge Taylor Francis Group.

O’Neill JW and Carlbäck M (2011) Do brands matter? A comparison of breed and independent hotels' performance during a full economic cycle. International fournal of Hospitality Management 30(3): 515-521.

O'Neill JW and Mattila AS (2004) Hotel branding strategy: Its relationship to guest satisfaction and room revenue. Fournal of Hospitality \& Tourism Research 28(2): 156-165.

Papatheodorou A, Rosselló J and Xiao H (2010) Global economic crisis and tourism: Consequences and perspectives. Fournal of Travel Research 49(1): 39-45.

Pizam A and Holcomb J (2008) International Dictionary of Hospitality Management. Oxford. ButterworthHeinemann-Elsevier.
PricewaterhouseCoopers (2006) Standing out in a crowd: PricewaterhouseCoopers' fourth European Lifestyle Hotel Survey 2006. Hospitality Directions Europe Edition, (14 September 2006). Available at: www.hospitalitynet. org/file/152002774.pdf (accessed 10 March 2020).

Quesada FBC and Ruiz LG (2006) La integración y la cooperación en las estrategias de marketing relacional: El caso del sector hotelero internacional. Anuario furídico $y$ Económico Escurialense 39: 523-554.

Quintas MA (2006) Organização e Gestão Hoteleira. Lisboa: OtelTur.

Rushmore S (2005) A case for being independent. Hotels (February) 22. Available at: www.hvs.com/article/1732/ canadian-lodging-outlook-may-2005/ (accessed 10 March 2020).

Singh A and Dev SC (2014) Winners and losers during the Great Recession: The positive impact of marketing expenditure. Cornell Hospitality Quarterly 56(4): 383-396.

UNWTO (1997) Report on the development of the accommodation sector. Available at: www.e-unwto.org/doi/pdf/10. 18111/9789284411306 (accessed 10 March 2020).

UNWTO (2019) International tourist arrivals reach 1.4 billion two years ahead of forecasts (Press release). United Nations World Tourism Organization. Available at: www2.unwto. org/press-release/2019-01-21/international-tourist-arriv als-reach-14-billion-two-years-ahead-forecasts (accessed 10 March 2020).

Xotels (2019) The top five characteristics of independent hotels. Available at: https://xotelsmarketing.wordpress. com/2017/07/31/xotels-the-top-5-characteristics-of-inde pendent-hotels/ (accessed 10 March 2020).

\section{Author Biographies}

Sofia Almeida holds a $\mathrm{PhD}$ in Tourism (University of Lisbon - Institute of Geography and Spatial Planning - IGOT), with the thesis: "The phenomenon of coopetition in hotel networks - the case of hotel marketing consortia." Sofia is researcher in Centro de Estudos Geográficos - Territur Unit's, part of IGOT, Universidade de Lisboa. She is a researcher in the areas of hotel management, hotel marketing consortia and hotel branding, as well as in 'coopetition' and social networks. She began the collaboration with Universidade Europeia (ISLA) in 2009, as a lecturer in the areas of tourism, hotel marketing and digital marketing. Since 2018, Sofia has acted in the capacity of assistant professor and also coordinator of the Hotel Management program at the Universidade Europeia's Faculty of Tourism and Hospitality Management.

Valerie Sheppard is an Associate Professor with the Universidade Europeia's (UE) School of Tourism \& Hospitality. She researches in the areas of tourism ethics, destination sustainability, and intercultural tourism and hospitality management. She is a field notes editor for the Journal of Ecotourism and a reviewer for many academic journals. Valerie holds a $\mathrm{PhD}$ in the 
Environment from Simon Fraser University, Canada. She also holds a MA in Leisure \& Recreation Studies, and a Bachelor's degree in Tourism Studies, both from Brock University, Canada.

Carlos Costa holds a $\mathrm{PhD}$ and MSc on Tourism Management (University of Surrey, UK), and a BSc on Urban and Regional Planning (University of Aveiro, Portugal). Carlos is the leader of the Tourism Research Unit and of the PhD Tourism Programme of the University of Aveiro. $\mathrm{He}$ is also Scientific Coordinator of the "idtour-unique solutions" (tourism spin-off company of the University of Aveiro), a private sector company located in the University, responsible for the transference of knowledge and innovation to the tourism sector. Carlos is involved in a number of national and international tourism projects.

José Manuel Simões is the President of IGOT Institute of Geography and Spatial Planning University of Lisbon (since 2019); Full Professor at IGOT - University of Lisbon (since 2006); Scientific Coordinator of $\mathrm{PhD}$ on Tourism of IGOT University of Lisbon (since 2010); Scientific Coordinator of TERRITUR: unit for Tourism, Culture and Territory Studies at Centre for Geographical Studies - IGOT - University of Lisbon (since 2008); Member of the Executive Board of
IUPEA - International Urban Planning and Environment Association (since 2014); and author of numerous papers and headed several research and consultancy projects on regional/local development and tourism strategic planning.

Raquel Costa has a $\mathrm{PhD}$ in Clinical Psychology from the University of Minho. Between 2009 and 2013 she taught at the University of Trás-os-Montes and Alto Douro in undergraduate and master's degrees in Clinical Psychology, Education Psychology and Special Education. Currently and since 2011, is an assistant professor at the Faculty of Healthy Sciences of the Europeia University, where she teaches in undergraduate and graduate programs. Her research interests focus on developmental psychopathology, psychophysiology of early interactions and behavioral genetics, being in these areas principal investigator of projects funded by FCT and Bial Foundation. Other research interests focus on the epidemiology of mental illness, being an integrated member of EPIUNIT (Epidemiology Research Unit) of the Institute of Public Health of the University of Porto. As a result of her research work, she has been integrating national and European project research teams and has published in international scientific journals. Her productivity and impact are evaluated at this time with Scopus Index $\mathrm{H}=10$. 